\title{
Beata Pawłowska
}

Uniwersytet Łódzki

https://doi.org/10.18778/1733-8069.9.2.06

\section{Czynniki wpływające na powstawanie i/lub ukrywanie emocji w pracy przedstawiciela handlowego i nauczyciela}

Abstrakt Celem artykułu jest pokazanie czynników wpływających na powstawanie emocji społecznych, takich jak duma, wstyd, poczucie winy, zażenowanie oraz emocji podstawowych, takich jak smutek, złość, strach, występujących w sytuacji pracy. Czynniki te zostały omówione na przykładzie dwóch grup zawodowych, to jest nauczycieli i przedstawicieli handlowych. Podstawę teoretyczną stanowiły koncepcje zaliczane do nurtu socjologii interakcjonizmu symbolicznego. Szczególnie ważne dla niniejszych rozważań były myśli June Tangney i Thomasa Scheffa. Analizę empiryczną oparto na badaniach autorki przeprowadzonych z użyciem wywiadów swobodnych i narracyjnych oraz obserwacji. W artykule poruszono problem interakcji jako głównego czynnika wpływającego na emocje w pracy zawodowej. Omówiono kolejno interakcje ze współpracownikami, z przełożonymi, klientami, organizacją, w tym interakcje odnoszące się do regulacji prawnych.

Słowa kluczowe emocja, emocje społeczne, interakcja, duma, wstyd, nauczyciel, przedstawiciel handlowy, obserwacja, wywiad swobodny

Beata Pawłowska, absolwentka socjologii i psychologii. Doktor nauk humanistycznych. Adiunkt w Katedrze Socjologii Organizacji i Zarządzania IS UŁ. Wykładowca wielu studiów podyplomowych, członek kilku zespołów badawczych. Badacz kultury organizacyjnej oraz zachowań emocjonalnych w środowisku pracy. Specjalizuje się w zarządzaniu emocjami, zarządzaniu zasobami ludzkimi, komunikowaniu społecznym oraz psychologii motywacji, emocji i osobowości.

\section{Dane adresowe autorki:}

Katedra Socjologii Organizacji i Zarządzania

Instytut Socjologii Uniwersytetu Łódzkiego

ul. Rewolucji 1905 r. 41/43, 90-214 Łódź

e-mail: pawlowska.beata@gmail.com że problematyka emocji wyłania się jak gdyby "przy okazji” badania innych zjawisk lub grup społecznych, czego również doświadczyła autorka niniejszego artykułu. Dlatego też do badania emocji szczególnie przydatną metodologią może być teoria ugruntowana (the grounded theory), za twórców której uważa się Barneya G. Glasera oraz Anselma L. Straussa (1967). Najkrócej mówiąc, metodologia ta jest budowana w sposób indukcyjno-dedukcyjny, który umożliwia maksymalną bliskość badacza z przedmiotem jego badań. Tworzona jest na bieżąco w trakcie badań, bez wcześniejszych założeń (hipotez) i nie jest tworzona a priori. Cechuje ją łatwość operacjonalizacji, gdyż pojęcia, jakimi operuje, wywodzą się z wyodrębnionego obszaru badań. „Generowanie teorii z materiału empirycznego znaczy tutaj, że większość hipotez i pojęć nie tylko wyłania się z danych, lecz także jest systematycznie tworzona w oparciu o nie" (Glaser, Strauss 1967: 6). Dzięki bliskości badacza z aktorami społecznymi jest on w stanie dotrzeć do ich schematów poznawczych i odkryć subtelności w definiowaniu przez nich rzeczywistości społecznej. Zastosowanie w niniejszych badaniach elementów teorii ugruntowanej pozwoliło między innymi na nieprzyjmowanie wcześniejszych założeń, generowanie hipotez $\mathrm{w}$ trakcie analizy materiału empirycznego oraz na procesualne ujęcie badanej problematyki.

Zaprezentowany $\mathrm{w}$ artykule materiał empiryczny stanowi jedynie fragment większych badań, które dotyczyły uwarunkowania emocji społecznych w środowisku pracy nauczycieli i przedstawicieli handlowych. Badania prowadzone były w grupie obecnych (czynnych zawodowo) oraz byłych przedstawicieli danego zawodu ( $w$ grupie byłych nauczycieli były to osoby będące na emeryturze, a w grupie przedstawicieli handlowych osoby wykonujące obecnie inny zawód).

Wybór przedstawicieli handlowych był dla mnie oczywisty ze względu na fakt konieczności wykonywania przez tę grupę zawodową pracy nad emocjami, a także odbywania przez nią licznych i wszechstronnych szkoleń, w tym, między innymi, z negocjacji, manipulacji oraz zarządzania emocjami. Należy zaznaczyć, że pomiędzy przedstawicielami handlowymi są znaczne różnice. Legitymują się oni zarówno wykształceniem średnim (np. w branżach technicznych - sprzedaż narzędzi, pieców centralnego ogrzewania), jak i wyższym (np. lekarze pracujący jako przedstawiciele medyczni). Są to osoby w różnym wieku (choć przeważają osoby poniżej czterdziestego roku życia) oraz zajmujące różne szczeble $\mathrm{w}$ hierarchii firm (od merchandiserów po dyrektorów handlowych będących w randze członków zarządu firmy). Dla przejrzystości analitycznej $\mathrm{w}$ dalszej części artykułu wszystkie te osoby nazywane będą przedstawicielami handlowymi.

Badając przedstawicieli handlowych i analizując otrzymywany materiał, kategorie analizy powoli ulegały nasyceniu. Autorka zaczęła się wtedy zastanawiać, czy praca emocjonalna przebiega $\mathrm{w}$ taki sam sposób w innych grupach zawodowych. Szukając odpowiedniej grupy porównawczej, ważne było, aby były to osoby mające w pracy bezpośredni kontakt z klientem, a jednocześnie wykonujące pracę emocjonalną. Grupą taką okazali się nauczyciele pracujący w szkołach podstawowych, gimnazjach i liceach. Już na etapie analizy wywiadów przeprowadzonych $\mathrm{z}$ osobami pracującymi w różnych 
zawodach ${ }^{1}$ okazało się, że grupą wyróżniającą się pod względem opowieści zabarwionych emocjonalnie jest grupa nauczycieli. Wskazywali oni częściej niż inni na konieczność wykonywania pracy emocjonalnej, a jednocześnie narzekali na brak szkoleń z zakresu radzenia sobie z trudnymi emocjami i podkreślali specyficzny charakter pracy nauczyciela. Właśnie te czynniki spowodowały, że grupa osób wykonujących zawód nauczyciela stała się grupą porównawczą.

Techniki zbierania danych, jakie zostały zastosowane dla realizacji celu, to między innymi wywiad

Należy zaznaczyć, że wybór nauczycieli jako grupy porównawczej da niniejszych badan poprzedzony był analiza wywiadów przeprowadzonych z osobami będącymi przedstawicielami rożnych grup zawodowych. Podczas zajęc z psychologii pracy oraz zajęc z socjologii pracy i organizacji analizowaliśmy ze studentami kariery osób wykonujących różne zawody. W ramach ćwiczen studenci poproszeni zostali o przeprowadzenie jednego wywiadu z osobą pracującą od ponad dwudziestu lat. Następnie szukalismy podobienstw w przebiegu ich karier zawodowych. Patrzylismy, na jakie aspekty życia pracowniczego najczęsciej wskazują rozmówcy. Okazało się, że jedną z głównych kategorii był rodzaj występujących pomiędzy pracownikami interakcji oraz wzbudzanie przez nich określonych emocji. Rozmówcy wskazywali ponadto na dumę z przynależności do grupy pracownikow danego przedsiębiorstwa albo $\mathrm{z}$ tego samego powodu ukrywali wstyd. Wskazywali na porażki i sukcesy, zal i radość. Zatem emocje pojawiły się jak gdyby „przy okazji” wyróżniania kolejnych kategorii analizy. Kolejnym krokiem było rozszerzenie badań zapoczątkowanych podczas zajéć z psychologii pracy oraz socjologii pracy i organizacji. I tak, w ramach badań własnych, przeprowadzono 30 wywiadów swobodnych małoustrukturalizownych z osobami pracującymi. Zaznaczyć należy, że były to osoby w różnym wieku, pracujące na różnych stanowiskach i w różnych branżach. Wywiady te dotyczyły przebiegu ich kariery zawodowej, ze wskazaniem na punkty zwrotne $\mathrm{w}$ ich karierze, elementy pracy, takie jak stres organizacyjny, wypalenie zawodowe, pracoholizm, aktywność lub bierność zawodowa oraz zjawiska zwiazzane z dyskryminacja na rynku pracy i w samej organizacji. Wywiady te dotyczyły również procesu motywowania pracowników, ze szczególnym wskazaniem na wartości i priorytety życiowe oraz motywatory skłaniajace do efektywnej pracy przy uwzględnieniu stanów emocjonalnych towarzyszących wykonywanym zadaniom oraz aktualnym wydarzeniom $\mathrm{w}$ miejscu pracy. W wyniku wstepnej analizy jakosciowej zebranego materiatu ponownie odnale-

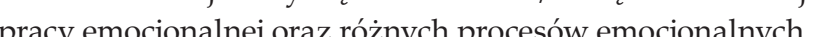

swobodny (małoustrukturalizowany oraz ustrukturalizowany), wywiad narracyjny oraz obserwacja (uczestnicząca, quasi-uczestnicząca, ukryta oraz półjawna i jawna), przy czym obserwacja dotyczyła także spostrzegania zachowań badanych w sytuacji wywiadu.

Ponieważ emocje widoczne są w języku ciała i modulacji głosu, to najlepszą moim zdaniem techniką do ich badania jest obserwacja uczestniczaca jawna lub ukryta. Pozwala ona dostrzec wszystko to, czego nie dostrzega i nie uświadamia sobie sam badany, a także umożliwia zobaczenie przedmiotu badań bez nadmiernej ingerencji badacza. Dlatego dziwić może fakt, że obserwacje są dość rzadko wykorzystywaną techniką w badaniach nad emocjami.

Obserwacja, jako technika popularna wśród socjologów organizacji (Doktór 1964; Konecki 1992) pozwoliła na weryfikację informacji udzielanych przez badanych, umożliwiła zaobserwowanie emocji towarzyszących sytuacjom stresowych, a także sformułowanie dalszych pytań wobec badanych Dłuższy kontakt zarówno z przedstawicielami handlowymi, jak i nauczycielami oraz uczniami sprawił, że po jakimś czasie osoba badacza przestawała być obiektem zainteresowania ze strony osób badanych, co miało istotne znaczenie dla jakości uzyskanych w ten sposób danych. Technika obserwacji uczestniczącej pozwoliła z kolei na pokazanie, jak interakcja wpływa na „zarażanie się" emocją dumy.

\section{Autorka artykułu przeprowadziła:}

1. cztery całodniowe obserwacje uczestniczące ukryte/półjawne podczas całodziennych, jednodniowych szkoleń przedstawicieli handlowych (szkolenia wstępne oraz szkolenia $\mathrm{z}$ wiedzy o sprzedawanych produktach, nazywane w dalszej części pracy szkoleniami wiedzowymi);
2. dwie całodniowe obserwacje uczestniczące ukryte/półjawne podczas dwóch dwudniowych szkoleń przedstawicieli handlowych (szkolenia integracyjne oraz podsumowujące wyniki pracy)

3. cztery całodniowe obserwacje quasi-uczestniczące ukryte podczas całodziennych, jednodniowych i dwudniowych szkoleń przedstawicieli handlowych prowadzonych między innymi przez autorkę niniejszego artykułu (szkolenia z tak zwanych umiejętności miękkich oraz z technik sprzedaży);

4. cztery obserwacje jawne podczas całodziennych, jednodniowych szkoleń przedstawicieli handlowych (szkolenia różnego typu, w których autorka była biernym obserwatorem);

5. dwanaście obserwacji jawnych podczas innych spotkań organizacyjnych handlowców;

6. trzy obserwacje jawne dnia pracy handlowca, podczas których autorka towarzyszyła przedstawicielom handlowym w czasie podróży samochodem (dwie z tych obserwacji przeprowadzone były podczas coachingu - $\mathrm{w}$ aucie poza przedstawicielem handlowym i autorką znajdował się także bezpośredni przełożony przedstawiciela handlowego, który miał za zadanie obserwować wykonywane przez niego czynności oraz udzielać wskazówek do lepszej i efektywniejszej pracy);

7. szesnaście obserwacji jawnych podczas zajęć lekcyjnych prowadzonych na terenie szkół;

8. trzydzieści dwie obserwacje uczestniczące ukryte podczas zebrań i spotkań nauczycieli z rodzicami oraz rodziców w ramach zebrań rady szkoły;

9. dwie obserwacje jawne podczas zebrań samych nauczycieli, tak zwanych rad pedagogicznych;
10. jedną obserwację ukrytą podczas rady pedagogicznej (autorka występowała tu w roli przedstawiciela rady rodziców).

Należy zaznaczyć, że podczas zebrań rodziców i nauczycieli z rodzicami oraz podczas szkoleń przedstawicieli handlowych (10 obserwacji) autorka nie ujawniała swojej tożsamości badacza. Podczas zajęc lekcyjnych obserwowana była ekspresja emocjonalna oraz sposoby radzenia sobie z emocjami. Następnie, bezpośrednio po lekcji, rozmawiano z nauczycielem o powstałych w czasie zajęć lekcyjnych emocjach, przez co badana osoba miała możliwość odniesienia się do zaobserwowanych przez badacza faktów. Oferta szkoleniowa kierowana do grupy nauczycieli w czasie prowadzenia badań nie zawierała szkoleń dotyczących kierowania emocjami, dlatego też nie przeprowadzono obserwacji podczas szkoleń nauczycieli.

Technika wywiadu swobodnego stwarza z kolei możliwość bezpośredniego kontaktu z rozmówca i wytworzenia odpowiedniej atmosfery, co uważa się za bardzo pomocne w uzyskaniu pełnych, pogłębionych odpowiedzi. Istnieje także możliwość sterowania rozmową w zależności od zaistniałej sytuacji. Rozmowa umożliwia obserwację badanej osoby $\mathrm{w}$ trakcie wypowiedzi oraz stwierdzenie, w których momentach jest ona bardziej zaangażowana emocjonalnie, a w których mniej.

Innym typem wywiadu jest wywiad narracyjny, w którym najważniejszą rolę pełni rozmówca, spontanicznie układający swoją opowieść. Najczęściej dotyczy ona kariery zawodowej, przeżyć, które miały istotny wpływ na życiorys rozmówcy (w tym traumatycznych) oraz biografii (zob. Konecki 2000: 180). „Narracja jest rezultatem indywidualnych 
doświadczeń jednostki oraz szerszego, społeczno-kulturowego kontekstu, które razem mają wpływ na kategoryzacje ujawniane w narracji przez badanych" (Taylor, Littleton 2006: 23 za: Chomczyński 2008: 116). Technika wywiadu narracyjnego oparta jest na subiektywnych odczuciach. Jej zaletą jest elastyczność, wrażliwość i delikatność. Między innymi z tych powodów można uważać, że technika ta jest bardzo przydatna do badania emocji.

Techniki wywiadu swobodnego oraz narracyjnego wybrane zostały między innymi, aby pogłębić informacje uzyskiwane $\mathrm{w}$ trakcie obserwacji, określić powody występowania poszczególnych emocji oraz zdiagnozować ich źródła.

W wywiadach starano się zwrócić uwagę na istotne elementy występujące w pracy przedstawiciela handlowego oraz nauczyciela, ze szczególnym wskazaniem na momenty trudne (negatywne) i przyjemne (pozytywne). Technika wywiadu pogłębionego dała szansę stworzenia okoliczności zbliżonych do swobodnej rozmowy z badanym na interesujące badacza tematy (por. Przybyłowska 1978; Konecki 2000). Należy zaznaczyć, że pytania zadawane rozmówcom w trakcie wywiadów narracyjnych formułowane były na poziomie ogólnym, starano się unikać pytań wprost o emocje. Najczęściej pierwszym było poproszenie rozmówcy o opowiedzenie o swojej pracy, kolejne pytania pojawiały się w sytuacji krótkiej i ograniczonej narracji rozmówcy oraz w celu pogłębienia uzyskanych informacji. Opowieści o emocjach pojawiały się samoistnie i jako takie należy je zaliczyć do źródeł niewywołanych przez badacza. W wywiadach mających charakter wywiadów swobodnych małoukierunkowanych oraz ukierunkowanych rozmówcy proszeni byli o opowiedzenie o swojej pracy ze wskazaniem na pojawiające się $\mathrm{w}$ niej sytuacje emocjonalne - na przykład, kiedy wpadają w złość oraz jak sobie z tą złością radzą. Inaczej mówiąc, pytani byli o to, jakie mają sposoby na powściąganie lub rozładowanie określonych emocji, na przykład gniewu. Podobne pytania zadawane były wobec zachowań w stosunku do innych pojawiających się emocji, w tym głównie emocji społecznych. Trzeba jednak zaznaczyć, że nie o wszystkich emocjach rozmówcy mówili wprost, a najczęściej ukrywaną emocją był wstyd.

Przeprowadzono szereg wywiadów narracyjnych, swobodnych małoustrukturalizowanych oraz swobodnych ustrukturalizowanych z przedstawicielami handlowymi, nauczycielami oraz rodzicami dzieci uczęszczających do badanych szkół. Na uwagę zasługuje fakt, że podstawę i inspirację do pogłębionych wywiadów swobodnych stanowiły również nieformalne rozmowy z nauczycielami i rodzicami, które poprzedzały obserwacje i wywiady, jak również następowały po nich. Łącznie przeprowadzono 124 wywiady, których średni czas trwania wynosił 39 minut. Wywiady przeprowadzane były zarówno przeze mnie, jak i przez studentów Uniwersytetu Łódzkiego w ramach zajęć dydaktycznych.

Niniejsze badania prowadzone były w latach 20062012. Wywiady swobodne i narracyjne były nagrywane za pomocą dyktafonu, a następnie transkrybowane i opracowywane zgodnie z przyjętą metodologia. Podobnej analizie zostały poddane sprawozdania i notatki z prowadzonych obserwacji.

\section{Natura emocji}

Pytanie o naturę emocji pozostaje wciąż otwarte. $\mathrm{W}$ miarę rozwoju nauk społecznych o emocjach wiemy coraz więcej, jednak ze względu na fakt, że pozostają one $\mathrm{w}$ sferze indywidualnych doświadczeń jednostki, są jej naturalnym i spontanicznym wyposażeniem, do dziś nie ma jednoznacznych wskazań, czym są emocje, kiedy powstają, od czego zależą i jak nimi zarządzać.

Emocje są mechanizmami powstałymi na drodze ewolucji na przestrzeni setek lat (Tooby, Cosmides 1990). Człowiek wyselekcjonował takie zachowania i związane z nimi reakcje emocjonalne, które były funkcjonalne. Nie ma jednoznacznej definicji emocji. „Każdy wie, czym jest emocja, dopóki nie poprosić go o definicję" (Fehr, Russell 1984: 446 za: Oatley, Jenkins 2005: 95). Nico H. Frijda mówi, że emocja jest doświadczana jako szczególny rodzaj stanu psychicznego (Frijda 1986, por. Doliński 2004; Oatley, Jenkins 2005). Jest uwikłana w relacje człowieka z pewnymi obiektami. Inaczej mówiąc, w umyśle człowieka „istnieją stany afektywne i stany gotowości związane z obiektami oraz że stany te pokrywają się z tym, co nazywamy zwykle emocjami” (Frijda 2012: 57). Stan afektywny częściej odnoszony jest do ogólnie pojętego nastroju² (np. „rozbawiony”, „pogodny"), który ma najczęściej charakter krótkotrwały w przeciwieństwie do emocji, którym przypisuje się dłuższy czas trwania afektu, co jest jednym z elementów odróżniających te dwa pojęcia.

Emocje nie pojawiają się w swojej pełni od razu, ale muszą przejść pewien proces, który nazywać będę procesem emocjonalnym. Pojawienie się emocji zawsze ma swoją przyczynę i konsekwencje. Pierwszym etapem jest dostrzeżenie wydarzenia lub zachowania, którym najczęściej jest nieoczekiwany bodziec, mogący zmienić cel dążeń jednostki. Następuje ocena poznawcza wydarzenia, czyli rozpoznanie go jako znaczącego oraz kontekstowe warto-

$\overline{2}$ Więcej na temat analizy pojęcia "nastrój” oraz rozróżnienia pomiędzy obiektami i przyczynami stanów afektywnych czytelnik znajdzie w pracach Nico Frijdy (Natura emocji pod reGdańskie Wydawnictwo Psychologiczne w 1998 i 2012 roku). ściowanie, czyli ocena pojawiających się myśli. Od nadania wartości zależy pojawienie się gotowości do działania, czyli tworzenie planów w odniesieniu do wydarzenia, tak aby zachować lub zmodyfikować cel. Od nadania wartości zależy także pojawienie się zmian somatycznych oraz ekspresji mimicznej i pantomimicznej. W ostatniej fazie pojawia się działanie właściwe, będące odpowiedzią na wytworzenie planu działania potwierdzającego dążenie do zamierzonego celu lub modyfikującego podjęte już działanie lub modyfikujące cel dążeń. Na tym etapie jednostka rozważa prawdopodobne rezultaty działań i podejmowanych decyzji. Następuje tu upublicznienie swoich emocji i skupienie się na interakcji z otoczeniem.

Istnieje wiele definicji emocji. Zależne są one między innymi od przyjmowanej perspektywy badawczej, od badanego problemu oraz od dyscypliny naukowej, jaką reprezentuje badacz. W związku z tym, że celem niniejszego artykułu nie jest przegląd definicji emocji, poniżej skupię się na zdefiniowaniu emocji z perspektywy socjologicznej, w nurcie interakcjonizmu symbolicznego. Emocje będę zatem rozumieć jako procesy stanowiące wynik specyficznej relacji między organizmem a środowiskiem (Lazarus 1991). To rozumienie emocji bliskie jest ujęciu Josepha J. Camposa i in., w którym emocje to „procesy, które ustanawiają, podtrzymują, zmieniają lub przerywają reakcję między jednostką a środowiskiem w sprawach ważnych dla jednostki” (1994: 285). Definicja ta nawiązuje do interakcji pomiędzy jednostką a środowiskiem, a wzajemny ich wpływ służy tworzeniu i utrzymywaniu relacji społecznych.

Mówiąc o emocjach, należy wspomnieć o jednym z elementarnych podziałów emocji - na podstawowe i pochodne. Choć w literaturze przedmiotu nie ma całkowitej zgody co do tego, które emocje należy uznać za podstawowe, to najczęściej wymienia 
sie tu za Paulem Ekmanem, Wallacem Friesenem i Ronaldem Simonsem (1985) strach, złość, smutek, radość, wstręt i zaskoczenie ${ }^{3}$. Uznano je za podstawowe, gdyż są doświadczane i rozpoznawane przez wszystkich ludzi (Doliński 2004: 364).

Dla socjologów bardziej interesujące są emocje pochodne, nazywane też emocjami wtórnymi lub społecznymi. Powstają one wskutek pojawienia się emocji podstawowych w specyficznych sytuacjach społecznych (Kemper 1987) i sa to na przykład: poczucie winy, wstyd, nadzieja, duma. Emocje pochodne są bardziej podatne na wpływ społeczny, czyli w większym stopniu są tworzone przez społeczeństwo (Lewis, Haviland-Jones 2005: 72-86). Są one wypadkowymi emocji pierwotnych. To głównie emocje społeczne, takie jak poczucie winy, duma i wstyd opisane zostaną $\mathrm{w}$ niniejszym artykule, choć odwołam się również do czynników wpływających na powstanie emocji złości, radości i strachu.

Emocja jest stanem subiektywnym. Jej odczuwaniu towarzyszą zwykle zmiany somatyczne, ekspresje mimiczne i pantomimiczne oraz specyficzne zachowania (Doliński 2004: 322). To na ich podstawie oceniamy umiejętności emocjonalne oraz zauważamy powstanie emocji u naszego partnera interakcji. Emocje spełniają szereg funkcji. Na interesującym mnie poziomie zachowania emocje pobudzają do działania i podtrzymują to działanie. Informują o rezultatach nieświadomej oceny istotnych $\mathrm{w}$ danym momencie zdarzeń oraz ukierunkowują uwagę jednostki na to, co dla niej ważne, dzięki czemu może ona decydować o podziale zasobów poznawczych będących w jej dyspozycji (zob. Wieczorkowska 2007: 175-176)

${ }_{3}^{3}$ Więcej na temat emocji podstawowych, jak i pochodnych czytelnik znajdzie w pracy Beaty Pawłowskiej Emocje spoteczne nakładem Wydawnictwa Uniwersytetu Łódzkiego w 2013 roku.
Jednostki, doświadczając emocji w sytuacjach interakcyjnych, bardziej lub mniej świadomie wpływają na przebieg własnych procesów emocjonalnych Posługują się przy tym różnymi strategiami. Mirosław Kofta (1979) opisuje trzy grupy takich strategii (zob. także Reykowski 1992: 48-50):

- oddziaływanie na sytuacje, które są źródłem emocji;

- oddziaływanie na procesy symboliczne (wewnętrzne), które mogą modyfikować emocje;

- podejmowanie czynności mających na celu zredukowanie lub wzmożenie pobudzenia (napięcia) emocjonalnego.

Do powyższych strategii dodać można strategię polegającą na podejmowaniu czynności mających na celu utrzymanie istniejącego napięcia emocjonalnego lub utrzymanie równowagi emocjonalnej.

\section{Emocje $w$ teorii interakcjonizmu symbolicznego}

W perspektywie paradygmatu interakcyjnego uczucia opisuje się jako tworzenie pojawiającego się doznania, w którym biorą udział czynniki społeczne. Owe czynniki wkraczają w emocje zarówno przed ich pojawieniem się, $\mathrm{w}$ trakcie tworzenia się emocji oraz po ich wystapieniu. $\mathrm{W}$ ramach tego paradygmatu wyróżnia się kilka koncepcji teoretycznych dotyczących pojmowania emocji - dramaturgiczne (Goffman), kulturowe (Hochschild, Gordon, Thoits, Clark), konstruktywistyczne (Averill), rytuału (Goffman, Collins, Summers-Effler), interakcjonizmu symbolicznego (Mead, Cooley, Stryker, Burke, Heise, Scheff, Tangeney).

W socjologii emocji teorie interakcjonizmu symbolicznego opisują życie społeczne poprzez perspek- tywę utrzymywania przez jednostkę pozytywnej opinii o sobie. Jeśli pojawia się zachowanie sprzeczne z korzystną samooceną, dochodzi do powstania uczucia dyskomfortu, które nazywa się dysonansem poznawczym (Reber 2002: 167). Tożsamość i koncepcja jaźni stają się regulatorami zachowań. Kiedy jednostki mają szansę podtrzymać koncepcję siebie, to doświadczać będą emocji pozytywnych, a jeśli im się to nie uda, będą doświadczać emocji negatywnych (i nastąpi mobilizacja do równoważenia). Jednostka czerpiąca informacje o sobie na podstawie samowiedzy oraz tego, co mówi o niej świat zewnętrzny (jaźń subiektywna i odzwierciedlona), stosuje mechanizmy obronne, jeśli nie ma możliwości potwierdzenia pozytywnego obrazu siebie. Strategie te stosowane są, gdyż emocje nieprzyjemne powodują ból, którego ludzie starają się unikać. To wszystko wpływa na zmianę zachowania, a co za tym idzie także emocji, które mogą być narzędziem socjalizacji (Turner, Stets 2009: 174-176).

Dla rozważań zawartych $\mathrm{w}$ niniejszym artykule istotne są dwie koncepcje teoretyczne. Po pierwsze, jest to koncepcja dumy i wstydu Thomasa Scheffa, a po drugie - koncepcja poczucia winy June Price Tangney.

\section{Koncepcja dumy i wstydu Thomasa Scheffa}

Jak piszą Turner i Stets, Thomas Scheff „łączy idee tradycji interakcjonizmu symbolicznego i psychoanalizy w ogólną teorię emocji" (2009: 174). Centralne miejsce zajmuje tu pojęcie wstydu powstającego z zakłopotania i zażenowania oraz dumy. Scheff korzystał między innymi z prac Cooleya, Goffmana, Freuda, Lewis i Adlera, gdzie na idei wstydu bazuje dążenie do prestiżu i poczucie niższości; Horney, dla której duma i wstyd były kluczem do zrozumienia zachowań normalnych i neurotycznych oraz Keltner i Buswell, gdzie wskazuje się na to, że wstyd widoczny jest $\mathrm{w}$ innej mimice. Jest to zażenowanie ukrywane (przykrywane) śmiechem (zob. Scheff 1990; 2000; 2002). Wstyd w koncepcji Scheffa jest pierwszą i najważniejszą emocją społeczną (Scheff 2000: 84), to cała rodzina emocji (zażenowanie, wina, nieśmiałość, zagubienie), które powstają w momencie zagrożenia więzi społecznej. Definicja ta stara się integrować jaźń (reakcje emocjonalne) i społeczeństwo (więzi społeczne) (zob. Scheff 1990). Emocje znajdujące się u podłoża jaźni odzwierciedlonej są podstawą kontroli społecznej. Duma pojawia się wtedy, gdy przestrzega się norm społecznych, a gdy się tego nie robi, pojawia się wstyd. Ponieważ jednostka dąży do odczuwania pozytywnych emocji, na przykład takich jak duma, to skutkiem jest konformizm społeczny i wysoki stopień stabilności społecznej. Zatem duma i wstyd zapewniają społeczną regulację zachowań bez konieczności zewnętrznego nadzoru (zob. Scheff 1990). Wstyd jest wynikiem obawy o wykluczenie z grupy, obawy przed odrzuceniem, negatywnego postrzegania siebie, niskiej samooceny, podporządkowania oraz oceną swoich działań jako niezgodnych z oceną rzeczywistości. Pojawienie się wstydu i dumy zależy od jakości relacji społecznych. Wstyd jest rezultatem negatywnych sankcji społecznych, a duma - wzajemnej akceptacji i szacunku (Stets 2006). Wstyd i poczucie winy są emocjami wtórny$\mathrm{mi}$, nadbudowanymi na emocjach negatywnych, takich jak złość, strach i smutek (Turner 2009). Duma to emocja wtórna nadbudowana na emocjach pozytywnych i wchodząca w skład rodziny emocji zadowolenia (Goleman 1997).

Duma i wstyd są podstawowymi społecznymi emocjami. Duma jest pozytywną emocją, która sprawia, że jednostki dostrajają się do swoich wzajemnych reakcji (przyjmując rolę innego) (zob. Turner, 
Stets 2009: 174). Duma jest sygnałem nienaruszonej więzi, a wstyd jest sygnałem więzi zagrożonej lub w jakiś sposób naruszonej. Jeśli idea więzi społecznej jest stłumiona, podobnie będą stłumione te dwa rodzaje emocji. Często używa się pewnego kodu językowego, by wyrazić lub ukryć określone emocje: „czułem się niepewnie”, „czułem się dziwnie", "czułem się niekomfortowo" i tym podobne. We współczesnych społeczeństwach zaprzeczenie wstydu jest zinstytucjonalizowane $\mathrm{w}$ języku. Wstyd i duma są ciągłymi sygnałami stanu więzi, ciągłym odczytywaniem temperatury relacji międzyludzkich. Kiedy jednostki doświadczają braku poważania i szacunku ze strony innych, same siebie oceniają negatywnie i doświadczają $\mathrm{w}$ ten sposób wstydu. Jeżeli wstyd jest uświadamiany, to może prowadzić do zdrowej rekonstrukcji więzi społecznej, jeżeli natomiast nie jest uświadamiany na skutek tłumienia czy wypierania, to uruchamia cykl wstydu i złości, który z kolei może doprowadzić do silnego zakłócenia więzi społecznych (Turner, Stets 2009: 175).

Scheff (za Helen Lewis) twierdzi, że wina należy do rodziny kategorii określających wstyd. Niepokój i poczucie winy mają swój społeczny komponent wstydu (Scheff 1990: 18). Ktoś raz zawstydzony może być zawstydzony tym, że jest już zawstydzony, przez co każdy stan zawstydzenia może być bodźcem dla dalszego odczuwania tej emocji, a osoby wstydliwe z natury mogą znaleźć się w chronicznym stanie wstydu.

Istnieją dwie możliwości negowania wstydu. Pierwsza występuje, gdy jednostka maskuje wstyd poprzez gesty i słowa. Odwraca spojrzenie, spowalnia mowę, zasłania twarz rękoma, używa zakodowanych słów, mówiąc, że czuje się głupio / nie w porządku / dziwnie i tym podobne. Druga ma miejsce wtedy, gdy jednostka dokonuje „obejścia” wstydu. Wykonuje ona demonstracyjne gesty (szybko mówi, szybko myśli, wykonuje gesty rękoma), zanim jeszcze zdąży doświadczyć wstydu. Wstyd w takiej sytuacji nie zostaje uświadomiony (Lewis 1971; Scheff 1990; 2000; 2002; zob. także Turner, Stets 2009: 174).

Na koniec warto wspomnieć o tym, że Scheff mówi również o ekspresji emocjonalnej i jej odczytywaniu. Twierdzi, że znaczenia wszystkich ludzkich ekspresji mają charakter kontekstualny. Znaczenie ludzkiej ekspresji nie jest raz na zawsze ustalone, ekspresja wskazuje tylko relacje pomiędzy sobą i kontekstem, w którym występuje. Innym źródłem wieloznaczności ekspresji jest sposób wypowiedzi oraz komunikacja niewerbalna (Scheff 1990: 37-38).

\section{Wstyd i poczucie winy w koncepcji June Tangney}

Inspiracją dla June Price Tangney (1994; 1995a; 1995b; 2002) były prace Thomasa Scheffa oraz Helen Lewis. W kręgu jej zainteresowań znalazły się dwie emocje: wstyd i poczucie winy, a jej koncepcja oraz badania wskazały na różnice pomiędzy tymi dwoma stanami emocjonalnymi. Choć obie emocje należą do grupy emocji społecznych, samoświadomych (Tangney 1995b) i moralnych, to Tangney wskazuje, że to poczucie winy, a nie wstyd, jest emocją ",moralną" (Tangney 2002), jest także według niej emocją bardziej użyteczną dla ludzi.

Zarówno poczucie winy, jak i wstyd są emocjami ocenianymi przez jednostki. Osoby oceniają swoje myśli, uczucia i działania z punktu widzenia swoich celów (Lewis 2000; Turner, Stets 2009). Ocena samego siebie może jednak odbywać się poza świadomością. Lewis wskazuje, że jednostki nie zawsze muszą być świadome procesu oceniania samych siebie, aby powstała określona emocja. Badania M. Csíkszent- mihályego oraz T. Figurskiego (1982) dowodzą, że ludzie rzadko myślą o sobie samych. Myśli dotyczące $\mathrm{Ja}^{4}$ pojawiały się zaledwie w 8 procentach wszystkich zapisywanych przez osoby badane spostrzeżeń dotyczących tego, co robili w danej chwili. Przeważająca część naszych codziennych myśli dotyczy banalnych spraw powszedniego życia, innych ludzi i naszych z nimi rozmów (Aronson, Wilson, Akert 1997: 221). Samoświadomość uruchamiana jest najczęściej w sytuacji, w której jednostka odczuwa obecność innych (np. gdy ktoś na nas patrzy) lub gdy zostanie do tego sprowokowana w sytuacji interakcyjnej (np. pytania innych osób dotyczące naszej osoby, zwrócenie uwagi na nasze zachowanie). Samoświadomość ma zatem miejsce wtedy, gdy jednostka koncentruje się na sobie, ocenia własne zachowanie i porównuje je ze swoimi wewnętrznymi normami i wartościami (Duval, Wicklund 1972; Wicklund 1975; Wicklund, Frey 1980 oraz Carver, Scheier 1981 za: Aronson, Wilson, Akert 1997: 222)

Bez względu na to, czy poczucie winy i wstyd pojawiają się w procesie świadomym czy nie, zawsze podlegają ocenie przez kogoś, kto danej emocji doświadcza. Wstyd angażuje w ocenę całą jaźń, bazuje na ocenie jaźni i odnosi się do całościowej oceny jednostki. Osoba doświadczająca wstydu ocenia siebie negatywnie jako taką (,jestem złą osobą"). Zawstydzone osoby chcą jak najszybciej uciec od źródła negatywnej emocji - chcą ukryć się, zniknąc, zapaść się

${ }^{4}$ Pojęcie Ja wprowadził do nauk społecznych William James (1890). Rozróżnił Ja "poznawane”, odnoszące się do naszych myśli i przekonań dotyczacych nas samych, nazywane w psychologii pojęciem Ja oraz Ja "poznające", będące aktywnym odbiorcą informacji i przetwarzającym informacje, nazywane samoświadomościa. $Z$ tego rozróżnienia wywodzi się późniejsza, socjologiczna koncepcja jaźni subiektywnej i jaźni odzwierciedlonej. Poza tym James podkreślał znaczenie relacji społecznych dla naszej definicji Ja. „,Człowiek ma tyle społecznych Ja, ile jest jednostek, które go rozpoznają i które
w swoich umysłach jakiś jego obraz" (James 1910: 294). pod ziemię. Tym samym dochodzi do przerwania interakcji społecznej. Wstyd sprzyja oddaleniu się od innych, oddzieleniu się, stwarza dystans w relacjach społecznych. Jednostka odczuwająca wstyd koncentruje uwagę na sobie i w ten sposób niezdolna jest do koncentracji na osobie skrzywdzonej, co jest warunkiem koniecznym do powstania współczucia. Ludzie doświadczający wstydu częściej kierują swój gniew na zewnątrz i winią innych lub sytuację (Tangney 2002). Można powiedzieć, że dochodzi u nich do atrybucji zewnętrznych, co pozwala im chronić własną jaźń przed zranieniem. Jednocześnie nie zauważają oni emocji partnera interakcji, przez co można określić je jednostkami mało empatycznymi.

Poczucie winy z kolei dotyczy oceny jedynie naszego działania, a nie całej osoby. Koncentrujemy się na źle wykonanym zadaniu, konkretnym wykroczeniu i jego następstwach. Pojawia się napięcie, wyrzuty sumienia, żal z powodu zrobienia czegoś złego (Tangney 1995b). Jednostka szybko podejmuje działania naprawcze. Zamiast uciekać, przeprasza, okazuje skruchę, naprawia wyrządzoną krzywdę. Następuje ponowne nawiązanie więzi społecznej. Tangney wskazuje, że poczucie winy jest dla relacji społecznych dobroczynne. Buduje poczucie współczucia i empatii poprzez koncentrację na skrzywdzonej osobie. Poczucie winy nie rodzi agresji, a prowadzi do konstruktywnego rozwiązania problemu.

Do rozważań Tangney należałoby dodać pogląd, że poczucie winy może prowadzić do powstawania wstydu. Poczucie winy o silnym natężeniu samo w sobie może zamienić się w emocję wstydu. W takiej sytuacji jednostka nie będzie podejmowała działań naprawczych. Poczucie winy może być także emocją udawaną (np. przestępca okazuje skruchę tylko w celu uzyskania mniejszej kary, gdy poczucie winy nie pojawiło się). 
Emocje w pracy nauczyciela i przedstawiciela handlowego

Celem artykułu jest pokazanie wybranych czynników wpływających na powstawanie i/lub ukrywanie emocji pojawiających się w środowisku pracy na przykładzie dwóch grup zawodowych, to jest przedstawicieli handlowych i nauczycieli. $\mathrm{W}$ toku analiz okazało się, że do ukrywania i manipulowania innymi emocjami najczęściej prowadzi powstanie emocji dumy, wstydu, zażenowania oraz poczucia winy. Złość była natomiast wynikiem zażenowania lub poczucia winy. Dlatego omawiając powstające emocje, odwoływać się będę przede wszystkim do wymienionych wyżej emocji społecznych. Uogólniając, należy powiedzieć, że do czynników wpływających na powstawanie emocji można zaliczyć:

- cechy pracy (czas pracy, dyspozycyjność, strategia i technika pracy, atmosfera w pracy);

- kulturę organizacyjną (rytuały, szkolenia, wyjazdy, język);

- $\quad$ sposoby motywowania (atmosfera w pracy, wynagrodzenie, ścieżka kariery, samorozwój, rodzaj relacji z szefem);

- interakcje pomiędzy pracownikiem a współpracownikiem z działu/szkoły; z pracownikiem z innego działu; z kierownikiem/dyrektorem; z klientem; z organizacją oraz interakcje odnoszące się do regulacji prawnych.

Poniżej zostanie omówiony tylko jeden, ostatni z wymienionych czynników, jako nadrzędny wobec wszystkich pozostałych.

\section{Interakcje pracownik - współpracownik}

Praca przedstawiciela handlowego oraz nauczyciela to praca z ludźmi i to oni są głównym czynnikiem wpływającym na powstawanie emocji w pracy omawianych grup zawodowych, zatem czynników powstawania emocji upatrywać należy w interakcjach społecznych. Najczęściej pojawiają się one w momencie naruszenia interakcji społecznej, przy czym należy pamiętać, że definicja emocji jest zawsze subiektywna i zależy od wielu cech jednostkowych.

Interakcje przedstawicieli handlowych i nauczyciel z ich kolegami z pracy mają głownie charakter osobisty, przyjacielski i zawodowy. Część rozmówców (dotyczy to głównie przedstawicieli handlowych) wskazywała na rywalizację, jednak w większości przypadków są to relacje pozytywne, budzące sympatię, a nawet przyjaźń. Oparte są one o emocje zaufania, wzajemnego szacunku, zadowolenia oraz o pomoc i wsparcie.

U mnie w firmie pracują, pracują przede wszystkim osoby młode w przedziale od 20 do 40 lat. Są bardzo fajni i często po pracy się spotykamy. Nie ma u nas zawiści. Staramy się sobie nawzajem pomagać i wspierać. [przedstawiciel handlowy, kobieta, 26 lat]

Lubię kilka osób. Spotykamy się po pracy. Nasze dzieci się znają [...]. [nauczyciel, kobieta, 36 lat]

$[\mathrm{W}]$ szyscy $\mathrm{w}$ firmie znamy się jak przysłowiowe łyse konie. Nie jest źle, skoro mówimy ze sobą nawet o kwestiach prywatnych. Potrzebne jest zaufanie [...] warto stworzyć $\mathrm{w}$ pracy atmosferę sprzyjającą kontaktom, wymianie poglądów [...], rodzą się, jak wszędzie, sympatie i antypatie. [przedstawiciel handlowy, mężczyzna, 36 lat]

Z wieloma osobami utrzymuję kontakty. Są to moi przyjaciele. Są to ludzie, z którymi yyy, no mogę sie zawsze spotkać na grillu przy yyy szklance piwa i pogadać. [przedstawiciel handlowy, mężczyzna, 37 lat]

Jednak były też wypowiedzi wskazujące na afekt ujemny. Niektórzy przedstawiciele handlowi wskazywali na zawiść i ogromną rywalizację.
Bardzo dobre, bardzo wszystkich lubie i wszyscy mnie lubią yyy i bardzo ładnie to wszystko wygląda. Jest miło, sympatycznie, ale zawsze jest jeszcze drugie dno. Okazuje się, że handlowcy to są po prostu wilki. Jeden na drugiego patrzy jak na ofiarę, jakby mu tylko podebrać firmę yyy, oszukać go, wykorzystać i zostawić. No tacy handlowcy są. [przedstawiciel handlowy, mężczyzna, 44 lata]

Należy jednak zaznaczyć, że rywalizacja nie zawsze miała konotację pejoratywną. Wielu rozmówców wskazywało na nią jako bodziec do intensywniejszej pracy. Można także stwierdzić, że rywalizacja prowadzi do powstawania poczucia satysfakcji i dumy.

[P]raca ta zawsze daje jakąś satysfakcję. Zawsze jest jakaś rywalizacja między nami tutaj $\mathrm{w}$ regionie, zawsze, jeżeli się spotykamy, wiadomo, kto najwięcej sprzedał, kto był najlepszy w tym, i zawsze, jeżeli ja jestem tam w okresie najlepszym, zawsze jest taki, taki moment satysfakcji i jednak takiej dalszej motywacji do tej pracy iii działania. [przedstawiciel handlowy, mężczyzna, 27 lat]

Rywalizacja jest bardzo duża, rywalizacja polega na tym, że oczywiście nikt nie chce być najgorszy, przede wszystkim to jest podstawowa rzecz, ale to ma taki pozytywny wymiar. Motywuje do działania. [przedstawiciel handlowy, mężczyzna, 30 lat]

Rywalizacja pełni ważny czynnik motywacyjny. Z punktu widzenia kierowania emocjami pracowników stanowi ważny sposób działania prowadzący do powstawania satysfakcji, dumy, a także do zwiększania identyfikacji pracowników z organizacją, do której przynależą. Z drugiej strony może jednak prowadzić do powstawania poczucia winy lub wstydu w sytuacji gdy zamierzony cel nie zostaje osiągnięty lub gdy zostaje osiągnięty w sposób moralnie naganny. W zaprezentowanej poniżej wypowiedzi odnaleźć możemy niepokój, strach, irytację, a nawet złość. Obserwując rozmówcę podczas wywiadu, można było także zauważyć ukrywany wstyd $^{5}$

Jesteśmy tylko słupkami. Szef na spotkaniu tygodniowym, miesięcznym, kwartalnym pokazuje tylko słupk [chodzi o wykresy z wynikami sprzedaży - przyp. BP], eeee. Ja jestem fioletowa. Jak tylko sprzedaż jest gorsza to dostajesz opierdziel. Jak jest dobrze, to pochwały nie usłyszysz. Czyli jak jest źle, to cię wyrzucą. Pracujesz do czasu, kiedy twój słupek nie spadnie poniżej magicznej linii. [przedstawiciel handlowy, kobieta, 27 lat]

Nauczyciele z kolei częściej wskazywali na klikowość oraz na zazdrość pomiędzy koleżankami z pracy.

Niełatwo pracuje się $\mathrm{w}$ środowisku prawie samych kobiet. Co rusz któraś zazdrości. A to, że było się na wczasach w Tunezji, albo że masz nowy ciuch. Od razu są komentarze, że Ci się w głowie poprzewracało, bo mąż dobrze zarabia. Staram się nie zwracać na to uwagi. [nauczyciel, kobieta, 29 lat]

Najtrudniej było, jak awansowałam na wicedyrektora i chciałam wyegzekwować, aby koleżanki były na dyżurach na korytarzach podczas przerw. Przecież jest to wymóg. Od tego zależy bezpieczeństwo dzieci. U nas w szkole dzieci są różne i trzeba przypilnować. A koleżanki od razu, niby w żartach, mówiły, że mi stanowisko do głowy uderzyło. Co nie jest prawdą. Ja tylko dbam o bezpieczeństwo dzieci. [nauczyciel, kobieta, 49 lat]

Uogólniając, można stwierdzić, że interakcje pomiędzy badanymi przedstawicielami handlowymi i nauczycielami a ich współpracownikami wpływały na powstawanie zarówno emocji pozytywnych, takich jak zaufanie, zachwyt, akceptacja, duma zainteresowanie, radość, jak i emocji negatywnych, takich jak strach, lęk, obawa, smutek, żal, uprzedzenie, pogarda, oburzenie, złość, wstyd, zazdrość, zdziwienie i dezaprobata.

${ }^{5}$ Problematyka odczytywania emocji, w tym emocji wstydu i dumy, podczas wywiadu szerzej omówiona została w tekście niem. Problemy metodologiczne, opublikowanym w $2012 \mathrm{r}$. 
Jakość i intensywność interakcji ze współpracownikami przekłada się na ocenę satysfakcji z pracy, ale - co ważniejsze - wpływa na budowanie jaźni odzwierciedlonej. Pracownicy chętnie słyszą pochwały ze strony kolegów i koleżanek z pracy, co pozwala im na odczuwanie dumy, radości i zadowolenia, a unikają informacji (stosują zaprzeczenie, usprawiedliwianie, racjonalizację lub inne techniki neutralizacyjne) mogących wywołać smutek, poczucie winy lub wstyd. Stosowanie jednej z takich technik można zaobserwować w przytoczonym powyżej cytacie. Unikanie lub aranżowanie sytuacji mogących wywołać określone emocje społeczne przekłada się na częstotliwość interakcji. Szczególnie w grupie badanych nauczycieli można było wyraźnie zauważyć sympatyzujące ze sobą grupy pracowników. Podczas obserwacji rad pedagogicznych można było spostrzec zachowania wskazujące na przeniesienie interakcji na grunt towarzyski. Obserwowani często rozmawiali ze sobą i to zarówno przed rozpoczęciem rady, w jej trakcie, jak i po jej zakończeniu. Wymiana stanowisk i poglądów odbywała się głównie w sympatyzujących ze sobą grupach. Rozmowy dotyczyły problematyki pracy, ale także sytuacji prywatnych. W przypadku zaatakowania jednej z koleżanek, inne, z sympatyzującej grupy, podejmowały jej obronę, a nawet atakowały grupę przeciwna.

Zarówno nauczyciele, jak i przedstawiciele handlowi okazują wzajemną sympatię poprzez zajmowanie podczas zebrań, rad pedagogicznych i szkoleń miejsc obok siebie, wzajemne przygotowywanie kawy czy herbaty oraz dzielenie się zakulisowymi informacjami. Osoby pozostające poza sympatyzującym kręgiem z reguły siadają po przeciwnych stronach lub z boku. W grupie przedstawicieli handlowych wzajemne wsparcie widoczne jest także w pomaganiu sobie na różnych testach sprawdzających wiedzę, a w grupie nauczycieli w udostepnianiu konspektów zajęć i innych materiałów dydaktycznych.

\section{Interakcje pracownik - przełożony (kierownik} dyrektor)

Tak jak współpracownicy, tak i przełożeni stanowią dla badanych osób źródło emocji. Przedstawiciele handlowi wskazują na bezpośrednich i pośrednich przełożonych jako czynnik wzbudzający podziw, sympatię, zaufanie, zadowolenie (emocje pozytywne):

Ja szefa prawie nie widzę. Ma do mnie zaufanie. Ja jestem raczej w terenie niż tu na miejscu. [...] Jak potrzeba, to głównie kontakt telefoniczny lub mailowy. Ale tak jak mówię. Ja ufam jemu, a on mnie. Ta swoboda mi odpowiada. [przedstawiciel handlowy, mężczyzna, 31 lat]

Szef jest w Busku, a ja tutaj w Łodzi jeszcze $z$ dwoma kolegami. Raz w miesiącu się rozliczamy. Wtedy jedziemy do siedziby firmy. A jeżeli jest telefon, że masz przyjechać $\mathrm{w}$ tak zwanym międzyczasie, to człowiek zaczyna myśleć, co się stało, o co chodzi, co spieprzyłeś. Wtedy może nie być miło. Ale takie sytuacje to rzadkość [przedstawiciel handlowy, mężczyzna, 37 lat]

Mogą oni także wzbudzać strach, obojętność, stres, wrogość, złość (emocje negatywne):

Nie przepadamy za sobą, normalnie bardzo poprawne. Ona nie przepada za mną i ja za nią. Zreszta nikt za nią nie przepada. [przedstawiciel handlowy, mężczyzna, 44 lata]

Należy zaznaczyć, że przedstawiciele handlowi, opowiadając o relacjach z przełożonymi, często nie wskazywali na bezpośrednich przełożonych. Zdarzały się narracje, w których rozmówca twierdził, że nie ma szefa, a dopytany, wskazywał, że szef „gdzieś jest, ale daleko" i on bardzo rzadko go widzi. Ci rozmówcy, opowiadając o swojej pracy, najczęściej wskazywali na interakcje z firmą, w której pracują, w związku z czym firmę jako taką można uznać za jednostkę zwierzchnią. $Z$ tego można wnioskować, że interakcje z przełożonymi nie są częste i że mają charakter horyzontalny. Opowieść o przełożonych pojawiała się $\mathrm{w}$ kontekście oceny pracy przedstawiciela handlowego. Najczęściej wskazywano na fakt podróżowania kierownika z przedstawicielem przez cały dzień według przyjętej „,trasówki” (kod in vivo) samochodem przedstawiciela i obserwacji zachowań podczas interakcji z klientami oraz podczas prowadzenia samochodu służbowego.

Jak wsiadało się z tym przedstawicielem, to chodziło o to, żeby on, jadąc samochodem oklejonym znakami firmy, nie robił jakichś paskudnych numerów. Wymuszał pierwszeństwa, zachowywał się wulgarnie, nieelegancko i tak dalej. On musiał również przenosić kulture firmy na całe otoczenie, to było bardzo istotne. [były przedstawiciel handlowy, kierownik, mężczyzna, 52 lata

Uogólniając, można stwierdzić, że emocje powstające na skutek interakcji przedstawiciel handlowy - przełożony oznaczone są w większości afektem pozytywnym lub obojętnym. W grupie badanych nauczycieli w narracji rzadko pojawiały się opowieści o przełożonych. Najczęściej występowały one w odniesieniu do nierównego podziału obowiązków, podziału nagród oraz przydziału klasy i jej wyposażenia. Klikowość szczególnie podkreślana była w relacjach z przełożonym.

Nagrodę [chodzi o nagrodę dyrektora przyznawaną przez dyrektora placówki dla najlepszego nauczyciela z okazji Dnia Edukacji Narodowej - przyp. BP] dostaje ten, kto jest bliżej pani dyrektor i ma z nią dobre układy. [nauczyciel, kobieta, 35 lat]

Nauczyciele wskazują nie tylko na nierówny podział nagród pieniężnych (np. nagroda dyrektora lub dodatek motywacyjny), ale także na nierówny dostęp do klas lekcyjnych wyposażonych w multimedia, możliwość (lub jej brak) uzyskania godzin nadliczbowych i płatnych zastępstw, lepszy plan zajęć, nauczanie $\mathrm{w}$ „lepszych" klasach. Ten nierówny podział dóbr szkoły może wynikać z niedoposażenia szkół oraz z faktu, że dyrektorem placówki oświatowej $\mathrm{z}$ reguły zostaje osoba pełniąca wcześniej funkcję nauczyciela w tej samej szkole. Implikuje to powstanie określonego rodzaju interakcji. $\mathrm{W}$ takie sytuacji osoby wcześniej zaprzyjaźnione z nową panią dyrektor (dyrektorami szkół najczęściej są kobiety) automatycznie tworzą nową koalicję i grupę posiadającą władzę. Szczególnie zwracały na to uwagę osoby będące poza kręgiem wpływów i poza grupa trzymającą władzę. Tacy nauczyciele wskazywali na chęć zmiany szkoły. Na chęć zmiany placówki oświatowej wskazywali również ci nauczyciele, którzy nie mieli dobrych relacji z koleżanką, która została nowym dyrektorem placówki.

Zjawiskiem mającym silny związek $\mathrm{z}$ interakcjami zachodzącymi pomiędzy nauczycielem a dyrektorem placówki, zwanym przez badanych „dyrekcją" (kod in vivo), jest często pojawiająca się $\mathrm{w}$ wypowiedziach klikowość. Rozmówcy podkreślali, że w szkołach widoczny jest podział sympatyzujących ze sobą grup. $\mathrm{Z}$ reguły jest grupa osób (klika) będąca blisko z dyrektorem szkoły i czerpiąca $z$ tego profity oraz grupa outsiderów, którzy nie mogą liczyć na pomoc i wsparcie dyrektora. Co ciekawe, o klikowości wspominali głównie ci respondenci, którzy zatrudnieni byli w placówkach, gdzie funkcję dyrektora pełniła kobieta.

Uogólniając, w relacji pracownik - kierownik/dyrektor najczęściej pojawiają się emocje pozytywne, takie jak duma, zaufanie, zachwyt, akceptacja, zainteresowanie, radość. Emocje negatywne, takie jak strach, lęk obawa, smutek, żal, oburzenie, złość, zdziwienie, dezaprobata, wstyd, pojawiają się najczęściej w sytuacji oceny pracownika.

Przegląd Socjologii Jakościowej • www.przegladsocjologiijakosciowej.org 


\section{Interakcje pracownik - klient}

Relacje przedstawiciel handlowy lub nauczyciel klient są jednym z ważniejszych czynników wpływających na powstawanie i kierowanie emocjami. Szczególnie istotne jest to dla przedstawicieli handlowych. W tej kategorii zawodowej ogólna tendencja do częstego przejawiania odczuć satysfakcji oraz szacunku w relacjach z klientami pozostawała na tym samym poziomie nasilenia co $w$ kategorii nauczycieli. Najczęstsze uczucia towarzyszące interakcji to sympatia oraz szacunek. Pojawiało się również uczucie obojętności. Szacunek, jako emocja powstająca w konsekwencji interakcji przedstawicieli handlowych z klientem, potwierdza tezę, że przedstawiciele handlowi zobowiązani są do deklarowania postawy szacunku względem swoich klientów. Z perspektywy interesów ekonomicznych firmy przedstawiciele handlowi wydają się $\mathrm{w}$ tym kontekście realizować odwieczne przykazanie dobrego sprzedawcy „,klient - nasz pan”. Duża liczba wypowiedzi wskazująca na pozytywne relacje z klientami może być rezultatem pozytywnie zapamiętanych transakcji i rozmów pomiędzy badanym a jego klientami. Należy zaznaczyć, że klientem wobec nauczyciela jest przede wszystkim rodzic i uczeń'.

Badani przedstawiciele handlowi wskazują na rodzaje klientów i stosowane wobec nich strategie. W pierwszym cytacie rozmówca dzieli klientów na zasadzie dychotomii na małomównych versus gadatliwych oraz miłych versus niemiłych. Jednocześnie występuje tu rodzaj emocjonalnej samoobrony, polegający na niedopuszczeniu do wystąpienia negatywnej emocji. Emocjonalna zasłona nakazuje dodać respondentce, że posiada ona raczej klientów sympatycznych, bo przecież z innymi by nie rozmawiała.

${ }^{6} \mathrm{O}$ relacji nauczyciel-uczeń i emocjach powstających na skutek tej interakcji traktuje inny artykuł autorki (Pawłowska, Chomczyński 2012).
Klienci są rożni: małomówni, gadatliwi, mili, nieprzyjemni. Oczywiście musimy rozmawiać z każdym, ale są wyjątki. Nie musimy przecież znosić chamstwa i agresji, a i takie przypadki się zdarzały. Ja osobiście nigdy sie z tym nie spotkałam. Raczej mam klientów sympatycznych. [przedstawiciel handlowy, kobieta, 26 lat]

Podobny mechanizm widoczny jest $\mathrm{w}$ kolejnym cytacie. Możemy tu ponadto łatwo zauważyć pojawiające się emocje dumy i satysfakcji. Rozmówca podkreśla fakt posiadania przez niego umiejętności komunikacyjnych oraz znajomość technik negocjacyjnych.

No wiadomo, jest różnie. Są różni kupcy w Polsce. Są tacy, że potrafią porozmawiać z człowiekiem, są nastawieni bardzo pozytywnie. Są tacy, od których każdą informację musisz wyciągać [...]. Takie nastawienie, że zawsze wszystko jest źle. To trzeba tak długo rozmawiać i przekonywać. Ja z tym nie mam problemu na szczęście. Potrafię zagadać, jak potrzeba. [przedstawiciel handlowy, mężczyzna, 23 lata]

Przedstawiciele handlowi często podkreślają pozytywne nastawienie klientów oraz miłą atmosferę podczas dokonywania transakcji i podpisywania umów. Wskazują na bezpośredni i nieoficjalny charakter interakcji.

W tych sklepach, w których mnie znają, no to jest super. Jest: „Panie Tomku [imię zmienione - przyp. BP] no witamy" i jest super gadka. Jest generalnie sympatycznie. [przedstawiciel handlowy, mężczyzna, 25 lat]

Ja już tam byłem słoneczkiem, kwiatuszkiem, skarbeczkiem, serduszkiem, no po prostu wszystkim, co możliwe już. Czekoladką nazywany nawet już byłem. Na początku to był dla mnie szok, jak zacząłem współpracować z tymi sklepami. Teraz już się przyzwyczaiłem i wiem, że tak jest. Przeszedłem z tego „pani” [rozmówca pokazuje cudzysłów] i mówię: „,Ej, dziewczyny". Widać, że tak chcą rozmawiać, to trzeba się przystosować, żeby było miło i sympatycznie. [przedstawiciel handlowy, mężczyzna, 23 lata]
Przedstawiciele handlowi, opowiadając o relacjach z klientami, często mówią o relacjach z klientami kobietami. Szczególnie dotyczy to branż spożywczych i kosmetycznych. Częściej zauważalne jest to wśród przedstawicieli handlowych zajmujących się sprzedażą bezpośrednio do mniejszych sklepów, nazywanych przez handlowców sklepami detalicznymi (kod in vivo). Rozmówcy obsługujący sklepy wielkopowierzchniowe lub hurtownie nie wskazują na tego typu zależności i nie dzielą klientów ze względu na płeć. Może to wynikać z faktu, że w handlu detalicznym pracuje więcej kobiet, zatem ci przedstawiciele handlowi mają częstszy kontakt z klientami kobietami. Kierownikami hipermarketów i hurtowni częściej są mężczyźni i być może stąd bierze się brak wyróżnika klientów w odniesieniu do ich płci.

[T]rzeba rozmawiać z pracownikami tych sklepów. Większość jest kobiet. Mnie się wydaje, że przedstawiciel to jednak facet. Ma dużo łatwiej. Kontakt z kobietą to jest zawsze jakoś tak, eee, takie mam wrażenie. Większość przedstawicieli to są jednak mężczyźni. I coś w tym jest, że łatwiej tam jakoś jest. Pani Jadziu, Pani Asiu, gadka szmatka i jakoś tam pójdzie. Pośmiejemy się razem i jest wesoło (śmiech). [przedstawiciel handlowy, mężczyzna, 28 lat]

Z kobietami jest sympatycznie, tyle że kobiety są takie, no bardziej koncentrują się na takich sprawach, takich pierdółkach. A mniej potrafią tak ogólnie powiedzieć, co w tym sklepie jest, a czego brakuje [...]. Nasza firma współpracuje ze sklepami S. To za PRL-u były już S. No to jest specyficzny w ogóle rodzaj sklepów. I takie moje spostrzeżenie. Inny personel tam pracuje. Kobiety, bo tylko kobiety tam pracuja, nie spotkałem żadnego mężczyzny, który by tam pracował, są bardzo specyficzne. We wszystkich prywatnych sklepach na początku jak przychodzę, to zawsze jest per pan, a tam od razu jest: „Ej ty". I ja przychodze, no wiadomo jestem młodym człowiekiem i też to jest inaczej. Dla tych kobiet jest to może jakaś sensacja, że młody chłopak sobie przyjeżdża. [przedstawiciel handlowy, mężczyzna, 23 lata]
W porównaniu do grupy badanych nauczycieli klienci u przedstawicieli handlowych prawie w ogóle nie wywołują irytacji, która jako występująca emocja pojawiła się $\mathrm{w}$ narracjach nauczycieli. Wypowiedzi nauczycieli wskazujące na irytację mogą świadczyć o ich większym wypaleniu zawodowym, większym stresie i większej nerwowości. Przedstawiciele handlowi podkreślają, że nie mogą okazywać irytacji w kontakcie z klientem. Muszą tu wykonywać pracę emocjonalną $\mathrm{w}$ celu utrzymania dobrych i trwałych relacji z klientem. Od tego zależy ich wynagrodzenie i pozycja w organizacji.

[J]uż mówiłem mu sześć razy. Opowiadałem, na czym to polega, a on po raz kolejny się pyta. Ja nie mogę pokazać irytacji. Muszę mu cierpliwie jeszcze raz odpowiedzieć na to pytanie. [przedstawiciel handlowy, mężczyzna, 36 lat]

W grupie nauczycieli nie obserwuje się takich zależności. Zatem na powstawanie i kierowanie emocjami mają wpływ czynniki strukturalne wynikające z sytuacji pracy. Teoretycznie, nauczyciel nie musi wykonywać głębokiej pracy emocjonalnej w kontakcie z uczniem lub rodzicem, gdyż od tego nie zależy jego wynagrodzenie i nie zależy mu na trwałości interakcji społecznej. Jednak w rzeczywistości taka praca jest wykonywana.

Nauczyciele, klasyfikując klientów, mówili o rodzicach nadopiekuńczych, ingerujących („,wtrącających się") $\mathrm{w}$ ich pracę, o rodzicach chcących zmieniać plan i sposób ich pracy, jak również niereagujących na uwagi nauczyciela $\mathrm{w}$ stosunku do zachowania ucznia. Zastanawiające są narracje, w których nauczyciele twierdzą, że rodzice nie wzbudzają u nich żadnych emocji. Może to świadczyć o braku zaangażowania tych nauczycieli w proces wychowawczy, o wysokiej umiejętności kontroli emocjonalnej lub o braku umiejętności zdefiniowania pojawiających 
się emocji. Irytacja mogła być także wynikiem efektu świeżości i mogła być podyktowana faktem wdrukowania w pamięć stanu irytacji jako wydarzenia zapamiętanego jednostkowo przez osobę badaną.

Najmniej uwag, przez co uznać należy, że nie jest to główny czynnik powstawania emocji negatywnych, mieli nauczyciele wobec uczniów. Szczególnie widoczne było to $\mathrm{w}$ grupie nauczycieli pracujących w szkole podstawowej w klasach młodszych. Twierdzili oni wprawdzie, że są sytuacje powodujące złość i frustrację lub smutek, ale wskazywali na chwilowy charakter tych emocji. $\mathrm{W}$ wywiadach podkreślali raczej pojawianie się emocji pozytywnych i wskazywali na uczniów jako źródło emocji przyjemnych.

Mam wspaniałą klasę. Te dzieci są takie słodkie [...]. Jest takich dwóch urwisów, ale idzie ich opanować. Gorzej z ich rodzicami, ale cóż, przecież dzieci nie są winne, że mają takich rodziców. [...] Tak raczej staram się pomóc uczniom z problemami wychowawczymi. [...] To jest takie przyjemne, jak podchodzi uczennica z laurką lub zwykłym rysunkiem i mówi: „Zrobiłam to specjalnie dla pani". Zawsze mnie to rozczula. [nauczyciel klas I-III, kobieta, 32 lata]

Nauczyciele niezmiernie rzadko wskazywali na sytuacje trudne i prawie w ogóle nie mówili o sytuacjach nacechowanych agresja, których podłożem byłaby złość. Większość twierdziła, że złe zachowania uczniów pokazywane w mediach nie mają miejsca w ich szkołach. Zgodnie podkreślali, że radzą sobie w klasach i panują nad zachowaniem uczniów, a w placówkach, w których pracują, nie ma przemocy.

Czasem zdarzy się, że ktoś tam się poszarpie. Jak to w szkole. Zawsze tak było. Ja sobie z tym radzę. U nas nie mamy większych problemów z uczniami. [nauczyciel, kobieta, 42 lata]

Jak ktoś mówi, że u niego uczniowie się nigdy nie pobili, to kłamie. [...] Przemocy u nas w szkole nie ma.
Dbamy o bezpieczeństwo i porzadek. [dyrektor gimnazjum, mężczyzna, 48 lat]

W narracjach nauczyciele częściej wskazywali na emocję dumy będącą pochodną faktu uczenia w danej, w tak zwanej „lepszej” klasie. Duma jest tutaj także wynikiem interakcji z przełożonym.

Od lat przejmuję klasy po pani X. To jest bardzo dobra nauczycielka i to są bardzo dobre i zgrane klasy. Świetne dzieciaki i rodzice też fajni. Dobrze, że tak jest. Cieszę się, że dyrekcja mnie docenia i daje mi te klasy. [nauczyciel, kobieta, 41 lat]

Wskazywali także na różnice $\mathrm{w}$ sposobie pracy z klasą.

Jak klasa jest lepsza, to z materiałem można iść szybciej. Lepiej uczy się w takich klasach. Więcej można wymagać. [nauczyciel, mężczyzna, 27 lat]

Zjawiska opisane powyżej nie wpływają w znacznym stopniu na emocje powstające $w$ pracy nauczyciela. Jeżeli $\mathrm{w}$ interakcji pomiędzy nauczycielem a uczniami dochodzi do powstawania u nauczyciela określonego rodzaju negatywnej emocji, to uczucie to ma krótkotrwały charakter. Poprzez posiadanie przez nauczyciela formalnego wysokiego statusu oraz formalnego wysokiego poziomu władzy negatywne emocje zamieniane mogą być na satysfakcję, na przykład z ukarania ucznia przejawiającego złe zachowanie. Poza tym można domniemywać, że nauczyciele ukrywają sytuacje trudne pojawiające się podczas lekcji ze względu na pojawianie się emocji wstydu. Sytuacje trudne oznaczają brak umiejętności pracy z klasą. Upublicznienie informacji o sytuacji trudnej, to przyznanie się do porażki i braku kompetencji w pracy z uczniami.

Choć w wywiadach mało jest narracji, w których nauczyciele opowiadaliby o sytuacjach negatywnie emocjonalnych występujących w klasie szkolnej, to jest grupa nauczycieli, która przyznaje się do występowania emocji o ujemnym zabarwieniu emocjonalnym. Najczęściej dotyczy to sytuacji i emocji, które miały miejsce w przeszłości. Nauczyciele podkreślają, że czasami nie potrafią poradzić sobie z emocjami powstającymi w trudnych sytuacjach.

Miałam kiedyś w klasie dziewczynkę, która miała bardzo trudną sytuację rodzinną. Ojciec pił, a matka poszła gdzieś w świat. A to dziecko opiekowało się rodzeństwem. Wiedzieliśmy o tym w szkole, ale nie bardzo można było pomóc. Trochę finansowo z TPD kupowaliśmy odzież, pomoce, książki, ale nie bardzo można było pomóc. Przeżywałam to bardzo. Rozmawiałam z nią. Starałam się okazać ciepło, serdeczność i trochę miłości. Miałam nadzieję, że uda się uratować dziewczynę, bo to było bardzo miłe dziecko. Nawet parę razy zabrałam ją do siebie do domu, żeby pobawiła się z moją córką. Nic więcej nie mogłam zrobić. Po kilku latach ją spotkałam i niestety rozczarowanie. Dziewczyna się stoczyła. Przykro mi było. Nawet teraz, kiedy to pani opowiadam, to czuję żal i taką niemoc. [nauczyciel, kobieta, 43 lata]

Brak umiejętności radzenia sobie z emocjami powstającymi w klasie szkolnej częściej dotyczy nauczycieli z niewielkim stażem pracy. Takich, którzy nie wypracowali jeszcze własnych sposobów pracy z klasą i tym samym sposobów reakcji na sytuacje trudne emocjonalnie pojawiające się $\mathrm{w}$ pracy z uczniami.

Uogólniając, emocjami pozytywnymi pojawiającymi się $\mathrm{w}$ wyniku interakcji pomiędzy badanymi grupami zawodowymi a klientami były emocje dumy, satysfakcji, zaufania, akceptacji, wdzięczności oraz wzajemny szacunek. Emocje negatywne pojawiały się rzadziej i były to irytacja, złość, wstyd, lęk, obawa, smutek i dezaprobata.

\section{Interakcje pracownik - organizacja}

Pod pojęciem interakcji pracownik - organizacja rozumieć będę interakcje odnoszące się do sposobu or- ganizacji pracy, identyfikacji z organizacja, regulacji prawnych i interakcje z przedmiotami, takimi jak samochód, GPS czy komputer (na te ostatnie wskazywali jedynie badani przedstawiciele handlowi).

Większość rozmówców podkreślała fakt lubienia swojej pracy. Nauczyciele wspominali o identyfikacji z placówką oświatową. Pomimo tego, że nauczyciele wskazują na obciążenie pracą zawodowa trudności w oddzieleniu pracy zawodowej od życia prywatnego, klikowość, pojawiającą się złość wobec placówki, bezradność w stosunku do systemu edukacji, to jednocześnie deklarują głęboką identyfikację z placówką. Można zauważyć zależność identyfikacji z placówką od długości stażu pracy - im dłuższy staż pracy w danej placówce oświatowej, tym głębsza $\mathrm{z}$ nią identyfikacja. Można stwierdzić, że nauczyciele nie różnią się pod tym względem od innych grup zawodowych. Przeważnie identyfikacja pracownika z przedsiębiorstwem rośnie wraz z długością stażu pracy. Jednocześnie należy zauważyć, że młodsi stażem nauczyciele nie wykazywali identyfikacji ze swoim miejscem pracy, na co wskazują wypowiedzi mówiące o czasowym charakterze pracy w szkole.

Jestem tu z przypadku. Popracuję ten rok, może dwa i jak znajdę coś innego, to się przeniosę. Praca z dziećmi to chyba nie dla mnie. [nauczyciel, mężczyzna, 25 lat]

Czasowy charakter pracy widoczny był także $\mathrm{w} w \mathrm{w}-$ powiedziach przedstawicieli handlowych. Często podkreślali oni, że jest to praca dla ludzi młodych, charakteryzująca się dużą rotacyjnością. Być może czasowy charakter pracy - a co za tym idzie - brak identyfikacji z organizacją, dla której pracujemy, jest syndromem dzisiejszych czasów i dotyczy wszystkich młodych ludzi. 
Ciekawym miejscem w pracy nauczyciela jest pokój nauczycielski, w którym nie tylko zachodzą interakcje pomiędzy nauczycielami, ale także sam w sobie budzi emocje. Jest miejscem wymiany doświadczeń oraz odpoczynku po zajęciach lekcyjnych, przez co budzi zadowolenie i radość. Nauczyciele nie mają szkoleń (tak jak przedstawiciele handlowi) z zakresu radzenia sobie $z$ trudnymi emocjami. Wzajemne rady oraz opowieści o trudnych sytuacjach i sposobach poradzenia sobie z nimi pomagają wykonywać głęboką pracę emocjonalną.

Staram się oddzielić pracę i dom. Choć czasem nie jest to łatwe. Czasem cierpią moje dzieci, ale nigdy nie przenoszę sytuacji z domu do szkoły. Uczniowie
nie cierpią z powodu moich problemów. Nauczyciel kłopoty powinien zostawiać przed drzwiami szkoły. [nauczyciel, kobieta, 37 lat]

Pokój nauczycielski jest też miejscem budzącym lęk, strach, obawę, smutek, złość i wstyd. Szczególnie dotyczy to sytuacji, w których nauczyciel nie chce spotkać niepożądanych przez siebie osób. Może być miejscem plotek, drwin i drobnych złośliwości, których nauczyciele wolą unikać. Dlatego niektórzy z nich mówią, że sporadycznie wchodzą do pokoju nauczycielskiego. Miejsce odpoczynku stanowi dla nich pracownia lekcyjna.

Innym czynnikiem wpływającym na powstawanie emocji w pracy nauczyciela są wszelkie zmiany w programach nauczania i brak jednolitej polityki edukacyjnej. W przeprowadzanych wywiadach nauczyciele wskazywali na problemy wynikające ze stale dokonywanych reform edukacyjnych. Był to najczęściej wymieniany przez nauczycieli powód powstawania negatywnych emocji. Zaznaczyć należy, że część wywiadów realizowana była w okresie wprowadzania przez Ministerstwo Edukacji Narodowej nowego minimum programowego, stąd być może częste zwracanie na to uwagi przez badanych nauczycieli.

Od nowego roku wchodzi nowe minimum, ale do chwili obecnej nie ma zaakceptowanego wykazu podręczników. Rodzice proszą o listę podręczników na przyszły rok, a ja co mam im powiedzieć, że Ministerstwo jak zwykle się spóźnia? [nauczyciel, kobieta, 42 lata]

Ostatnia grupa czynników wpływających na powstawanie emocji w pracy odnosi się jedynie do przedstawicieli handlowych i są to interakcje z przedmiotami, takimi jak samochód, laptop, telefon, GPS i inne urządzenia elektroniczne. Choć może się to wydawać czytelnikowi mało istotne, to handlowcy z dużą ekspresją emocjonalną opowiadali o prowadzeniu samochodu, sytuacjach na drodze, niemożności znalezienia danego sklepu z powodu ciągłych remontów dróg, płaceniu mandatów, GPS-ie w samochodach, konieczności rozliczania przejechanych kilometrów zgodnie z wcześniej zaplanowaną trasą, wolno działających komputerach oraz o braku Wi-Fi i tym podobnych. Interakcje z przedmiotami budziły większe emocje u badanych przedstawicieli handlowych niż interakcje ze współpracownikami, klientami i przełożonymi.

GPS to jest tragedia i moim zdaniem to jest głupota. Naprawdę to jest głupota, ponieważ pracownik nie ma elastyczności, a jednak trasy przedstawiciela handlowego, przedstawiciela producenta muszą być elastyczne. [przedstawiciel handlowy, mężczyzna, 36 lat]

Jazda samochodem jest dla badanej grupy przedstawicieli handlowych stresująca i nerwowa. Przedstawiciel handlowy spędza średnio połowę czasu swojej pracy w samochodzie. Sytuacje na drogach wywołują silne emocje, gdyż są nieprzewidywalne i niezależne od jednostki. Wielość czynników oraz ich nieregularność i zmienność powoduje, że jednostka nie radzi sobie z przetwarzaniem ogrom- nej ilości bodźców. Wywołuje to frustrację i może prowadzić do stresu. Interakcja z klientem może być zaplanowana, wyszkolona i wyćwiczona, co zmniejsza ryzyko porażki i jednocześnie zwiększa prawdopodobieństwo pojawienia się pracy emocjonalnej. Trudno natomiast przewidzieć awarię samochodu, blokadę pasa drogowego, brak oznakowania, korki na drogach i inne podobne zdarzenia. Sytuacje drogowe wpływają na czas pracy i są pośrednim czynnikiem determinującym ocenę pracy przedstawiciela handlowego, na wykonanie założonego planu sprzedaży i w konsekwencji na wynagrodzenie, przez co wpływają na zachowania emocjonalne.

Łódź jest strasznie oznakowana. To jest po prostu koszmar. Czasami niektóre ulice znaleźć jest sukces. A później ten numer i sklep to już jest $\mathrm{w}$ ogóle. I to samo na wsiach. [przedstawiciel handlowy, mężczyzna, 23 lata]

Interakcje z przedmiotami powodują złość, frustrację, lęk, strach, ale także zaufanie, akceptację i dumę.

\section{Podsumowanie}

Zjawiska opisane powyżej $\mathrm{w}$ znacznym stopniu wpływają na emocje powstające $w$ pracy nauczyciela i przedstawiciela handlowego. $\mathrm{W}$ toku badań okazało się, że podobnie jak w grupie nauczycieli, tak i w grupie przedstawicieli handlowych można wyróżnić trzy główne grupy sytuacji wywołujących emocje w ich pracy. Pierwsza z nich to sytuacje wynikające $\mathrm{z}$ interakcji pomiędzy przedstawicielami handlowymi lub nauczycielami a ich współpracownikami i przełożonymi. Druga to sytuacje wynikające $\mathrm{z}$ interakcji z klientami. Ostatnia grupa wynika z uwarunkowań infrastrukturalnych, organizacyjnych, prawnych oraz z interakcji z przedmiotami, takimi jak samochód, telefon, GPS. Ta ostatnia gru- pa związana jest z faktem powiązania posiadania i funkcjonowania określonych przedmiotów z systemem motywacyjnym i wykonaniem pracy.

Przedstawiciele handlowi jako główny czynnik pojawiania się zarówno negatywnych, jak i pozytywnych emocji wskazywali współpracowników, bezpośrednich przełożonych, podwładnych lub klientów/kontrahentów. $\mathrm{W}$ wielu przypadkach pojawiały się także wskazania na samochód, komputer, GPS lub inne urządzenie elektroniczne, będące przyczyną pojawienia się negatywnych emocji. Źródłem emocji przedstawicieli handlowych w środowisku pracy są także szkolenia i systemy motywacyjne nieomawiane $\mathrm{w}$ niniejszym artykule. Jednocześnie należy zaznaczyć, że te same czynniki (ludzie, przedmioty) wywołujące $\mathrm{w}$ jednej sytuacji negatywne emocje, w innych sytuacjach wywoływały emocje pozytywne.

W odniesieniu do grupy badanych nauczycieli należy stwierdzić, że głównym źródłem emocji negatywnych są działania Ministerstwa Edukacji Narodowej, dyrekcji placówki, współpracowników (koleżanek i kolegów z pracy, rodziców uczniów) oraz w najmniejszym stopniu zachowania uczniów. Trzeba podkreślić, że zachowania uczniów wywołujące u nauczyciela negatywne emocje mają krótkotrwały charakter. Z racji jego autorytetu i władzy negatywna emocja szybko zamieniona zostaje na uczucie pozytywne. Nie oznacza to, że nie może powstać później poczucie winy lub inna emocja. Ze względu na tempo pracy w klasie i szybko zmieniającą się sytuację interakcyjną nauczyciel nie ma czasu zastanawiać się i nazywać powstających u niego emocji.

W tabeli 1 przedstawiono różnice pomiędzy obiema badanymi grupami w odniesieniu do źródła emocji. 
Tabela 1. Różnice pomiędzy nauczycielami a przedstawicielami handlowymi w odniesieniu do źródła emocji.

\begin{tabular}{|c|c|c|}
\hline \multirow{2}{*}{ Grupa badana } & \multicolumn{2}{|c|}{ Źródło emocji } \\
\hline & Emocje pozytywne & Emocje negatywne \\
\hline \multirow{8}{*}{$\begin{array}{l}\text { Przedstawiciele } \\
\text { handlowi }\end{array}$} & $\begin{array}{l}\text { Interakcje społeczne: } \\
\text { - ze współpracownikami } \\
\text { - z bezpośrednimi przełożonymi } \\
\text { - } \quad \text { z podwładnymi } \\
\quad \text { męż̇żami, w w tym relacje handlowców } \\
\quad \text { klientami kobietami }\end{array}$ & $\begin{array}{l}\text { Interakcje społeczne: } \\
\text { - } \quad \text { ze współłracownikami } \\
\text { - } \quad \text { z bezpośrednimi przełożonymi } \\
\text { - } \quad \text { z podwładnymi } \\
\text { z klientami }\end{array}$ \\
\hline & Komunikacja pośrednia & Komunikacja bezpośrednia \\
\hline & Pozytywna i miła atmosfera pracy & Negatywna i wroga atmosfera pracy \\
\hline & Rywalizacja jako motywator & Rywalizacja jako źródło złości i zazdrości \\
\hline & $\begin{array}{l}\text { Wysokość sprzedaży powyżej zakładanego } \\
\text { przez pracodawcę celu }\end{array}$ & $\begin{array}{l}\text { Nieosiaganie nałożonej przez pracodawcę wy- } \\
\text { sokości sprzedaży }\end{array}$ \\
\hline & 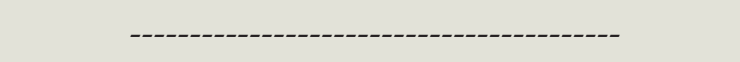 & Częste przebywanie poza domem \\
\hline & $\begin{array}{l}\text { Możliwość wykorzystania służbowego samo- } \\
\text { chodu i laptopa do celów prywatnych }\end{array}$ & $\begin{array}{l}\text { Przedmioty martwe (komputer, samochód, } \\
\text { GPS i tym podobne) }\end{array}$ \\
\hline & 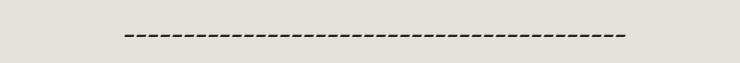 & Sytuacje drogowe \\
\hline \multirow{8}{*}{ Nauczyciele } & & $\begin{array}{l}\text { Brak jednolitej polityki Ministerstwa Edukacji } \\
\text { Narodowej: } \\
\text { • ciagłe zmiany w programach nauczania } \\
\text { - permanentne reformy w systemie oświaty }\end{array}$ \\
\hline & Pozytywna i miła atmosfera pracy & Negatywna i wroga atmosfera pracy \\
\hline & $\begin{array}{l}\text { Interakcje społeczne: } \\
\text { • } \quad \text { wspó́praca z dyrekcją placówki } \\
\text { - współpraca z kolegami i koleżankami } \\
\text { z pracy } \\
\text { - } \quad \text { współpraca z rodzicami } \\
\text { dzieci i młodzież szkolna }\end{array}$ & $\begin{array}{l}\text { Interakcje społeczne: } \\
\text { - } \quad \text { współpraca z dyrekcją placówki (klikowość) } \\
\text { - } \quad \text { brak współpracy z kolegami i koleżankami } \\
\text { - } \quad \text { pracy } \\
\text { - } \quad \text { rodzice ingółpracy z rodzicamący i wtrącający się w pracę } \\
\text { nauczyciela } \\
\text { - } \\
\quad \text { sytuacje trudne z uczniami zachodzące } \\
\quad \text { klasie szkolnej }\end{array}$ \\
\hline & $\begin{array}{l}\text { Pokój nauczycielski jako miejsce wymiany do- } \\
\text { świadczeń oraz głębokiej pracy emocjonalnej }\end{array}$ & $\begin{array}{l}\text { Pokój nauczycielski jako miejsce krytyki, emo- } \\
\text { cji złości, zazdrości i tym podobnych }\end{array}$ \\
\hline & Rada pedagogiczna & Rada pedagogiczna \\
\hline & Posiadanie autorytetu & Brak posiadania autorytetu \\
\hline & $\begin{array}{l}\text { Posiadanie zaplecza w postaci odpowiedniego } \\
\text { wyposażenia sali lekcyjnej }\end{array}$ & $\begin{array}{l}\text { Brak zaplecza w postaci odpowiedniego wy- } \\
\text { posażenia sali lekcyjnej }\end{array}$ \\
\hline & Monitoring szkoły & 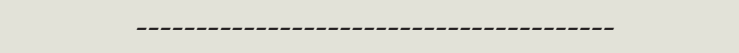 \\
\hline
\end{tabular}

Źródło: Opracowanie własne
Zdaję sobie sprawę, że niniejszy artykuł nie wyczerpuje wszystkich możliwości analizy materiału badawczego oraz nie przedstawia całości interpretacyjnej, jednakże pokazuje główne źródła emocji występujących w pracy przedstawicieli badanych grup zawodowych. Ciężar problematyki osadzony został wokół interakcji jako głównego źródła emocji społecznych. Można stwierdzić, że rozmówcy częściej opowiadają o przeżywanej emocji dumy niż o wstydzie czy poczuciu winy. Interakcja powodująca dumę jest wzmacniana między innymi poprzez częstotliwość kontaktów z osobą, która wywołu-

\section{Bibliografia}

Aronson Eliot, Wilson Timothy D., Akert Robin M. (1997) Psychologia społeczna. Serce i umyst. Przełożyła Anna Bezwińska i in. Poznań: Zysk i S-ka.

Campos Joseph J. i in. (1994) A Functionalist Perspective on the Nature of Emotion. „Monographs of the Society for Research in Child Development", vol. 59, no. 2-3, s. 284-303.

Csikszentmihalyi Mihaly, Figurski Thomas J. (1982) Self-awareness and aversive experience in everyday life. "Journal of Personality", vol. 50, no. 1, s. 15-28.

Doktór Kazimierz (1964) Przedsiębiorstwo przemystowe. Studium socjologiczne Zakładów Przemystu Metalowego "Cegielski". Warszawa: Książka i Wiedza.

Doliński Dariusz (2004) Mechanizmy wzbudzania emocji [w:] Strelau Jan, red., Psychologia. Podręcznik akademicki. Tom 2. Psychologia ogólna. Gdańsk: Gdańskie Wydawnictwo Psychologiczne, s. 319-349.

Ekman Paul, Friesen Wallace V., Simons Ronald C. (1985) Is the Startle Reaction an Emotion? "Journal of Personality and Social Psychology", vol. 49, no. 5, s. 1416-1426.

Fehr Beverley, Russell James A. (1984) Concept of emotion viewed from a prototype perspective . „Journal of Experimental Psychology", vol. 113, no. 3, s. 464-486. je emocję dumy. Interakcja powodująca powstanie emocji negatywnej jest wygaszana oraz uruchamia proces racjonalizacji. W tym zakresie można uznać, że koncepcja Tangney znalazła potwierdzenie wstyd sprzyja oddaleniu się od innych oraz stwarza dystans w relacjach społecznych. Dochodzi do przerwania interakcji społecznej. Odwołując się do koncepcji Scheffa, w której mówił o zarażaniu się zakłopotaniem, można powiedzieć, że w badanej grupie rozmówców pojawiło się zjawisko zarażania duma, co świadczy o tym, że tworzenie spirali emocji może także dotyczyć emocji pozytywnych.

Frijda Nico H. (1986) The emotions. Cambridge: Cambridge University Press.

----- (2012) Różnorodność afektu: emocje i zdarzenia, nastroje i sentymenty [w:] Paul Ekman, Richard Davidson, eds., Natura emocji. Podstawowe zagadnienia. Przełożył Bogdan Wojciszke. Sopot: Gdańskie Wydawnictwo Psychologiczne, s. 56-63.

Glaser Barney G., Strauss Anzelm L. (1967) The discovery of grounded theory: strategies for qualitative research. New York: Adline Publishing Company.

Goleman Daniel (1997) Inteligencja emocjonalna. Przełożył Andrzej Jankowski. Poznań: Media Rodzina of Poznań.

James William (1890) The principles of psychology. New York: Holt

----- (1910) The principles of psychology. London: Macmillan. Kemper Theodore D. (1987) How Many Emotions Are The re? Wedding the Social and Autonomic Components. „American Journal of Sociology", vol. 93, no. 3, s. 263-289.

Kofta Mirosław (1979) Samokontrola a emocje. Warszawa: Wydawnictwo PWN. 
Konecki Krzysztof (1992) W japońskiej fabryce. Łódź: Wydawnictwo Uniwersytetu Łódzkiego.

----- (2000) Studia z metodologii badań jakościowych. Teoria ugruntowana. Warszawa: Wydawnictwo Naukowe PWN.

Lazarus Richard S. (1991) Emotion and adaptation. London: Oxford University Press.

Lewis Helen (1971) Same and guilt in neurosis. New York: International Universities Press.

Lewis Michael (2000) Self-conscious emotions. Embarrassment, pride, shame and guilt [w:] Michael Lewis, Jeannette Haviland-Jones, eds., Handbook of emotion. New York: Guilford Press.

Lewis Michael, Haviland-Jones Jeannette M., eds., (2005) Psychologia emocji. Przełożyła Magdalena Kacmajor i in. Gdańsk: Gdańskie Towarzystwo Psychologiczne.

Oatley Keith, Jenkins Jennifer M. (2005) Zrozumieć emocje. Przełożyli Józef Radzicki i Jacek Suchecki. Warszawa: Wydawnictwo Naukowe PWN.

Pawłowska Beata (2012) Duma i wstyd jako emocje kierujace zachowaniem. Problemy metodologiczne. „Societas/Comunitas", vol. 2, nr 14, s. 39-54.

Pawłowska Beata, Chomczyński Piotr (2012) Sposoby radzenia sobie z emocjami negatywnymi na przykładzie grupy nauczycieli. „Studia Edukacyjne”, nr 21, s. 141-162.

Perna Giampaolo (2007) Zrozumieć emocje: poradnik. Przełożyła Barbara Bochenek. Kraków: Wydawnictwo OO. Franciszkanów „Bratni Zew”.

Przybyłowska Ilona (1978) Wywiad swobodny ze standaryzowana lista poszukiwanych informacji i możliwości jego zastosowania w badaniach socjologicznych. „Przegląd Socjologiczny", t. 30, s. 53-63.

Reber Arthur (2002) Stownik psychologii. Przełożyła Barbara Janasiewicz-Kruszyńska i in. Warszawa: Wydawnictwo Scholar.

Reykowski Janusz (1992) Emocje, motywacja, osobowosść. Warszawa: PWN.

Scheff Thomas J. (1990) Microsociology. Discurse, emotion, and social structure. Chicago: University of Chicago Press.
------ (2000) Shame and the Social Bond. A Sociological The ory. „Sociological Theory”, vol. 18, no. 1, s. 84-99.

----- (2002) Working class emotions and relationships. Secondary analysis of classic texts by Sennett and Cobb and Willis [w:] Bernard Phillips, Harold McKinnon, Thomas J. Scheff, eds., Toward a sociological imagination. Bridging specialized fields. Lanham MD: University Press of America, s. 263-292.

Stets Jan E. (2006) Identity Theory and Emotions [w:] Jan E. Stets, Jonathan H. Turner, eds., Handbook of the Sociology of Emotions. New York: Springer, s. 203-233.

Tangney June Price (1994) The mixed legacy of the super-ego: Adaptive and maladaptive aspects of shame and guild [w:] Joseph M. Masling, Robert F. Bornstein, eds., Empirical perspectives on object relations theory. Washington DC: American Psychological Association, s. 1-28.

----- (1995a) Recent Advances in the Empirical Study of Shame and Guilt. "American Behavioral Scientist", vol. 38, no. 8, s. 1132-1145.

----- (1995b) Shame and guilt in interpersonal relationship [w:] June Tangney, Kurt Fischer, eds., Self-conscious emotions: The psychology of shame, guilt, embarrassment and pride. New York: Guilford Press, s. 114-139.

------ (2002) Self-relevant emotions [w:] Mark Leary, June Tangney, eds., Handbook of self and identity. New York: Guilford Press, s. 384-400,

Tooby John, Cosmides Leda (1990) The Past Explains the Present: Emotional Adaptations and the Structure of Ancestral Environment. „Ethology and Sociobiology”, no. 11, s. $375-424$

Turner Jonathan H. (2009) Socjologia. Koncepcje i ich zastosowanie. Przełożyła Ewa Różalska. Poznań: Wydawnictwo Zysk i S-ka.

Turner Jonathan H., Stets Jan E. (2009) Socjologia emocji. Przełożyła Marta Bucholc. Warszawa: Wydawnictwo Naukowe PWN.

Wieczorkowska Grażyna (2007) Kierowanie motywacja: rola myśli i emocji. Warszawa: Wydawnictwo ISS.

\section{Cytowanie}

Pawłowska Beata (2013) Czynniki wpływajace na powstawanie i/lub ukrywanie emocji w pracy przedstawiciela handlowego i nauczyciela. „Przegląd Socjologii Jakościowej”, t. 9, nr 2, s. 128-151 [dostęp dzień, miesiąc, rok]. Dostępny w Internecie: «www.przegladsocjologiijakosciowej.org`.

\section{The Factors Influencing Arising and/or Hiding Emotions in the Context of Sales Representative and Teacher's Work}

Abstract: The aim of the paper is to show the factors affecting the formation of social emotions, such as pride, shame, guilt, embarrassment, and basic emotions, such as sadness, anger, fear, occurring within one's professional context. These factors are discussed basing on the example of two professional groups such as teachers and sales representatives. Theoretical basis for the analysis are provided Thomas J. Scheff and June Tangney's concepts. Empirical analysis is based on the author's research conducted with the use of the semi-structured interviews, covert and overt participant observations, and quasi-participant observations. In this paper the problem of interaction is shown as the main factor affecting experiencing emotions at one's professional context. Discussed are interactions with colleagues, interactions with supervisors, interactions with customers, interactions with the organization, including interactions relating to the law.

Keywords: emotions, social emotions, pride, shame, interaction, teachers, sales representatives, observation, semi-structured interview 